\title{
Study of citizen engagement in the participation of elective mandate actions in the Brazilian Legislature: analysis of the use of political techs
}

\author{
Jessica Natalia Souza Pavan ${ }^{1}$ \\ LUIS Hernan Contreras Pinochet ${ }^{1}$ \\ GABRIELA DE BRELÀZ ${ }^{1}$ \\ DURVAL LUCAS DOS SANTOS JÚNIOR ${ }^{1}$ \\ Daielly Melina Nassif Mantovani Ribeiro ${ }^{2}$ \\ 1 Universidade Federal de SÃo PaUlo (UNIFESP), OSASCO - SP, BRAZIL \\ ${ }^{2}$ UNIVERSIDADE DE SÃo PAUlo (USP), SÃo PAULO - SP, BRAZIL
}

\begin{abstract}
The innovation process of information and communication technologies have led to an increasing engagement of the population in political activities. Political techs emerge as an innovation to facilitate access to information and analysis of candidates during elections. They are used to monitor government actions and agendas, encouraging participation and civic engagement. This research analyzes citizen engagement through political techs adopted in elective mandates in the Brazilian Legislature after the general elections of 2018. The quantitative approach used a multivariate method of structural equation modeling with the application of a face-to-face survey with a sample of 467 university students. As a result, from the political techs, a model is proposed that allows the analysis by the citizens to inspect and participate in the decisions about the resources invested in the public policies and actions, being possible, thus, to foment the citizen's engagement.
\end{abstract}

Keywords: Political tech. Legislative mandate. E-participation. Engagement.

Estudo do engajamento do cidadão na participação de ações de mandatos eletivos no Legislativo brasileiro: análise do uso de political techs

\section{Resumo}

O processo de inovação das tecnologias de informação e comunicação promoveram o desenvolvimento de iniciativas que corroboram maior adesão popular às ações políticas. Diante disso, as political techs surgem como uma forma de inovação do uso da tecnologia para facilitar o acesso às informações e à análise dos candidatos para escolha durante a eleição e como meio de acompanhamento e monitoramento das ações e pautas de governo, auxiliando o processo de participação e engajamento cívico. Esta pesquisa teve por objetivo analisar o engajamento do cidadão, por meio do uso de aplicativos classificados como political techs, na participação em ações de mandatos eletivos no Poder Legislativo brasileiro após as eleições gerais de 2018. A abordagem quantitativa adotou método multivariado de equações de modelagem estrutural, com aplicação de um survey presencial com uma amostra de 467 universitários. Como resultado, a partir das political techs, é proposto um modelo que possibilita a análise por parte dos cidadãos para fiscalizar e participar das decisões sobre os recursos investidos nas políticas e ações públicas, sendo possível, assim, fomentar o engajamento do cidadão.

Palavras-chave: Political tech. Mandato no Legislativo. E-participação. Engajamento.

Estudio del compromiso ciudadano en la participación de las acciones del mandato electivo en el Poder Legislativo brasileño: análisis del uso de political techs

\section{Resumen}

El proceso de innovación de las tecnologías de la información y comunicación impulsaron el desarrollo de iniciativas que corroboran una mayor adhesión popular a las acciones políticas. Por lo tanto, las political techs surgen como una forma de innovación del uso de la tecnología para facilitar el acceso a la información y el análisis de los candidatos para elegir durante la elección y como medio de seguimiento y monitoreo de las acciones y pautas de gobierno, auxiliando el proceso de participación y compromiso cívico. Esta investigación tuvo como objetivo analizar el compromiso ciudadano a través del uso de aplicaciones clasificadas como political techs, en la participación en acciones de mandatos electivos en el Poder Legislativo brasileño después de las elecciones generales de 2018. El enfoque cuantitativo utilizó un método multivariado de ecuaciones de modelado estructural con la aplicación de una survey presencial con una muestra de 467 universitarios. Como resultado, desde las political techs, se propone un modelo que permite el análisis por parte de la ciudadanía para inspeccionar y participar en las decisiones sobre los recursos invertidos en las políticas y acciones públicas, siendo posible, así, fomentar el compromiso ciudadano.

Palabras clave: Political tech. Mandato en el Legislativo. E-participación. Compromiso. 
Study of citizen engagement in the participation of elective mandate actions in the Brazilian Legislature: analysis of the use of political techs
Jessica Natalia Souza Pavan | Luis Hernan Contreras Pinochet Gabriela de Brelàz | Durval Lucas dos Santos Júnior Daielly Melina Nassif Mantovani Ribeiro

\section{INTRODUCTION}

Interaction between citizens, civil society organizations and government enables the promotion of civic engagement and the expansion of the networked co-production process. This enables social control to be exercised more effectively, as a potential way to shorten the distance between powers and expand the interest of the population in political actions (YETANO and ROYO, 2016). The articulation between government (municipal, state and federal) actors and citizens must occur through mechanisms that encourage the population to engage in politics and foster interest in participating in the proposed decisions and policies.

Engagement denotes the spontaneous involvement of the citizen to access data and information. Its success depends on the ease of access to information and the ability of citizens to use knowledge by sharing and influencing people (BIMBER, 2001). The lack of engagement and participation of citizens makes them more distant, increases the lack of interest in politics and, consequently, decreases monitoring and participation in the actions and public policies of governments (FUNG, 2006).

Considering this perspective and the need to find mechanisms to bring citizens closer to government actions, information and communication technologies (ICT) can be a method to stimulate participation and bring people closer to government practices (HSU, CHANG and YEN, 2011). The instigation of participation becomes essential when it is proposed to research factors that would lead citizens to engage with the ICTs. This is done through initiatives involving interaction, control or participation; despite the technology allowing a greater number of people to have access to information, this does not mean that it is a fully democratic tool with full access to information and population participation.

Faced with the challenges of the Brazilian Legislative Power and seeking a way to stimulate the approximation and participation of citizens, The ICTs can constitute a mechanism of interaction. To understand whether people are prone to using new technologies to participate in the decisions of the Brazilian Legislative Power, it is necessary, as exhibited in Hirzalla, Zoone and Ridder (2010), to obtain a more refined understanding of the elements that precede their engagement. As an example, stimulated participation via mobile applications (apps) offers greater convenience and extends interactivity and network participation (FUNG, 2006; CHEN, 2015). In view of this, what is observed is that the use of technology focused on participation has gained more space in the public area. Additionally, the emergence in the political techs field of study, startups offer initiatives, through the development of technology-based solutions, to monitor and access information from candidates, mandates and complaints regarding parliamentary action.

However, despite the progress in research on the interaction and exchange of information through mobile media, there are still few studies that evaluate online political behavior and social participation in politics, especially regarding the use of political techs. Studies are also needed to investigate: a) how the use of these technologies can expand access to political participation; b) how these interactions occur between citizens, organizations, politicians and governments; and c) how they can produce distinct effects on decision-making (KIM and KLEINSCHMIT, 2012; MARTIN, 2014).

Lack of motivation granted to young people in this scenario, whether by family members, universities or the labor market, contributes to preventing them from being attentive to political affairs, causing the lack of interest in this area. Another contributing factor are the few public-private incentive initiatives to insert university engagement into the political context. It would be easier for the university student who wants to be part of his country's policy, to easily find initiatives that would update him and retain his interest in what occurs on the political scene. However, there are positive attributes of youth, associated with innovation and creativity with the support of technology, seen as agents with social change (SPOSITO and TARÁBOLA, 2016; PAULA and AFONSO, 2018).

The objective of this article is to analyze citizen's engagement by applications classified as political techs, in the participation in actions of elective mandates in the Brazilian Legislative Power after the 2018 general elections. 


\section{LITERATURE REVIEW}

\section{Citizen engagement and political participation}

Citizen engagement can be defined as the active participation of the citizen in the community to improve their conditions (ADLER and GOGGIN, 2005), prior to political participation. Most citizens' engagement activities can be classified as nonpolitical or semi-political, that is, not directly intended to influence parliamentarians and heads of the Executive Branch on issues of great importance to the community. There are also individual and collective forms of engagement and participation, so that each citizen has the power to choose when, how and by which means to engage politically (GIDDENS, 1991; EKMAN and AMNÅ, 2012).

Engagement is closer to how the individual will act in society, being driven by the feeling of collective improvement and not just by self-interest. Political participation has as its premise the individual's will to influence the results and decisions made by the rulers and may be involved in formal or informal activities and are not necessarily linked to political parties or government institutions. The citizen may be interested in formally participating in politics by choosing a candidate in the election, but that does not mean he will continue to participate beyond this act. Similarly, the citizen who is civically engaged can understand that participation, through the choice of candidates, adds nothing to the life of the community, preferring to act locally, without formally participating in politics.

Ekman and Amnå (2012) separate participation into three categories that should be considered in studies aimed at a better understanding of citizens. The first is non-participation: the individual is not interested and does not want to be interested in the subject, believing that politics does not affect his life. The second is linked to citizen/civic engagement: the individual is interested in improving the society in which he is inserted, understands that politics is something important and essential, but does not necessarily participate in politics. The third concerns formal political participation and activism, which is characterized by the active participation of citizens, either through voting or participation in political parties, organizations and social movements.

The concepts of civic engagement are still under construction, but it should be considered as an important starting point for seeking ways to expand the active participation of citizens in politics.

In this context, online participation and engagement have become important mechanisms of discussion and activism. The incorporation of the use of technology in several areas provides significant changes in the State and in the way of seeking citizens' engagement in Brazilian politics.

Several examples of civic engagement - Arab Spring, Occupy Movement in the United States of America (USA), June 2013 Days in Brazil - can shape the dynamics of governments and demand new processes be incorporated into governance structures (FOTH and BRYNSKOV, 2016). Fung, Gilman and Shkabatur (2013) present six models for the internet and politics, if digital technologies are transforming politics. However, there is great potential of the Internet to dramatically increase the quality of democratic governance, conversely, there are also indications, when examining the real standards of political activity and expression on digital platforms, that these forms of interaction are not capable of bringing equality or inclusion to democratic politics.

Other studies show that online engagement is still relatively low, but there are indications of influencing variables. For Zheng (2015), to better understand this phenomenon, in addition to exploring factors that affect the use of citizens' electronic participation, such as sociodemographic characteristics, use of internet, political perceptions, offline political activities, it is essential to analyze the functionality of electronic participation applications. According to the author, such applications are positively associated with the use of electronic participation of citizens and high-level functionality motivates them to increase the use of electronic participation. Zolotov, Oliveira and Castelevn (2018), in their work on electronic civic engagement, state, based on 60 studies, that the best predictors used in research models to study electronic participation are: a) trust; b) expectation of effort; c) perceived utility; d) attitude; e) trust in government; f) social influence on intention to use; g) perceived ease of use; h) perceived utility in attitude; and i) intention to use. 
Study of citizen engagement in the participation of elective mandate actions in the Brazilian Legislature: analysis of the use of political techs
Jessica Natalia Souza Pavan | Luis Hernan Contreras Pinochet Gabriela de Brelàz | Durval Lucas dos Santos Júnior Daielly Melina Nassif Mantovani Ribeiro

\section{The advancement of ICTs in the reformulation of the State in Brazil}

All initiatives related to electronic government, a concept that includes actions related to the processes and structure necessary to provide interaction between government and society, are based on 3 pillars: a) participation; b) collaboration; and c) transparency (DINIZ, BARBOSA, JUNQUEIRA et al., 2009). These pillars, together with the ICTs, enable government actions to become more efficient.

The development of ICTs in Brazil provided advances in several areas, however, its main use was in the improvement of the processes and management of the Executive Branch, although with little emphasis on citizen participation. Despite the scenario, participation can be recognized in initiatives ranging from the implementation of listeners in public agencies and the creation of complaint channels to public hearings and consultations. It is estimated that electronic governance actions are fundamental for a process of institutionalization and expansion of digital democracy. However, having a government that implements electronic government actions alone does not mean the country is progressing in digital democracy. It is essential that, together with electronic governance tools, a policy of encouraging digital democracy is created.

Rules, such as the Tax Responsibility Act (Complementary Law No. 101/2000) and the Law on Access to Information (Law No. $12,527 / 2011$ ) have in the ICTs a support to combat corruption, constituting examples of public policies that expand citizen participation and, primarily, social control.

E-participation is defined by the United Nations (UN) as the process of involving citizens, through ICTs, politics, decision-making and in the formulation and delivery of public services in a participatory way, which is inclusive and deliberative. However, it remains a more restricted practice for groups of younger people, who often use networks to share information, express support for candidates and discuss politics (YAMAMOTO, KUSHIN and FRANCIS, 2014).

Kardan and Sadeghiani (2011) treat e-democracy as the use of ICTs and information in democratic bodies and in the political process within communities. E-democracy is based on the processes and structures that allow for the interaction between representatives and constituents, through electronic media and an interaction channel. The main premise is the use of ICTs as tools to expand democratic participation, bringing the citizen to the political process, promoting accountability and greater interaction between the State and society, and enabling the expansion of the exercise of citizenship.

For ICTs to be, a mechanism for expanding social participation within mandates, whether from the Legislative Power or the Executive Branch, it is essential that there be a change in the way public management thinks. The government needs to consider the citizen part of the decision-making process, formulation, monitoring of public actions and policies (CUNHA and MIRANDA, 2013). Just as the citizen needs to understand that it is also his role to be a political and active subject in decision-making.

For Milani (2008), there is a demand for the renewal of relations between government and society and the need to redesign the type of representation exercised by traditional Brazilian politics. This representation that can be controlled using ICTs to improve this interaction, no matter if the information comes from an official source or fake news, because there will be discussion of the subjects. Social media has been used more emphatically in election campaigns. Web 2.0 technologies, such as blogs, social networking sites and video sharing sites, are increasingly seen as efficient tools with the power to change the election, as they enable the mapping of data taken from platforms and its integration into online marketing tactics, to influence citizens' choices (TOWNER and MUÑOZ, 2016).

Online participation can be defined as an extension of electronic participation concepts (e-participation), referring to the extensive use of mobile technologies and applications to expand electronic participation. With the opening of government data, many mobile apps are designed to provide smartphone users with information about cities or other information of public interest. Nevertheless, it is necessary to think about the ways of merging direct and indirect participation, including discussions within movements, institutional spaces and in the streets (SECCHI, 2009; CHEN, 2015; SECCHI, ALLEGRETTI and TANG, 2016).

Thus, ICTs can help increase civic engagement, as they allow citizens to consume, produce, distribute and comment on political news and information, creating opportunities to attempt to politically persuade other individuals. Social media associated with other participation mechanisms can therefore change the nature and impact of public policies, the opinion 
Study of citizen engagement in the participation of elective mandate actions in the Brazilian Legislature: analysis of the use of political techs
Jessica Natalia Souza Pavan | Luis Hernan Contreras Pinochet Gabriela de Brelàz | Durval Lucas dos Santos Júnior Daielly Melina Nassif Mantovani Ribeiro

of government leaders and, furthermore, establishes the first step towards the use of ICTs as a tool for citizen participation (WEEKS, ARDÈVOL-ABREU and ZÚNIGA, 2017).

For the promotion of effective citizen participation, it is necessary to create means to expand engagement and reduce obstacles to participation, either by the lack of skill in the use of ICTs due to the lack of interest in the theme, or lack of knowledge. The expansion of access to mobile devices positively influences democratic engagement, thus enabling the rapid connection of individuals, expanding the sense of belonging and enabling the connection of citizens with similar affinities. However, it is necessary to consider important factors in the engagement of people and movements, such as personal behaviors and attitudes about the use of these technologies (OSTMAN, 2012).

\section{Political techs}

The term political techs comes from political technology and refers to technologies developed and used for political purposes, whether in applications aimed at increasing voter turnout or software that analyzes big data to understand constituents. In the era of the fourth industrial revolution, there is a flood of new forms of political technology being built, all possible by internet and other technological advances.

Citizens need to understand political techs to become better able to participate and make decisions about their development, rather than relying on the goodwill of businesses or the States. In relation to the resurgence of democracy, it is necessary to understand what such technologies and what citizens can do. It is possible to use political techs to expand the scope of political representation beyond what currently exists. Political techs can represent our preferences and interests in a more complete and systematic way for citizens. The possibilities of these modes of political engagement may initially seem highly limited, due to the massive depoliticization of society in the information age. However, political apathy is also not a necessary result of the world in digital life.

James Susskind (2018) in "Future Politics" argues that society lives the "twilight of politics", because now the space of politics may be closing due to the development of more capable, integrative and invasive ICTs.

Monitoring the use of political techs is extremely important to enable citizens to monitor spending and the public budget. Thus, the application, in real time, in addition to bringing the citizen closer to the Legislative Power, becomes a facilitator to combat possible deviations from the treasury, and perhaps corrupt attempts. The development of local initiatives capable of promoting the insertion of citizens would enable the exercise of control of public expenditure, because the citizen plays a fundamental role, and should always exercise it outside of voting. Monitoring government proposals, as well as the public budget and, above all, the adherence of expenditure to regulated public policies would make for an aware citizen who is conscious of what the treasury should spend on programs, projects and public works, not allowing deviations of public money (KLEIN, 2019).

\section{THEORETICAL MODEL AND HYPOTHESES}

A theoretical model containing specific latent variables to be applied in this study was developed from Duane, O'Reilly and Andreev (2014), Kim and Sundar (2014), Venkatesh, Thong and Xu (2012) and Vivek, Beatty, Dalela et al. (2014). The following related constructs are the factors that influence the use of political tech applications by citizens to participate in mandates of elected officials in the Brazilian Legislative Power.

\section{Perceived Ease of Use}

The ease of perceived use is the degree to which a person believes that the use of a system should be effort-free or difficultyfree. This is linked with finite resources that must be allocated between various activities that are the responsibility of the person (DAVIS, 1989). This is understood, in this case, as the perception of a low effort to use applications, particularly regarding the technical skills required for the use and understanding of the service itself. Viehland and Yoong Leong (2010) and Duane, 
Study of citizen engagement in the participation of elective mandate actions in the Brazilian Legislature: analysis of the use of political techs
Jessica Natalia Souza Pavan | Luis Hernan Contreras Pinochet Gabriela de Brelàz | Durval Lucas dos Santos Júnior Daielly Melina Nassif Mantovani Ribeiro

O'Reilly and Andreev (2014) address in their studies the positive impact of the perceived ease of use on the propensity for consumption. Accordingly, the following hypotheses are given:

- $\quad \mathbf{H 1 a}(+)$ : Perceived Ease of Use positively influences Trust in the participation of actions of elective mandates in the Brazilian Legislative in the use of political techs.

- $\quad \mathbf{H} \mathbf{1 b}(+)$ : Perceived Ease of Use positively influences the Perceived Usefulness in the participation of actions of elective mandates in the Brazilian Legislative in the use of political techs.

\section{Perceived Usefulness}

Perceived usefulness refers to an individual's notion of increasing activity performance or the advantage that a specific system brings to those who use it. A system with a high degree of perceived utility is one in which its user sees a positive relationship between use and increased performance (DAVIS, 1989). The user experience refers to how the product is perceived, used and learned. To positively influence it, a user-centric product or service design is required, principally to influence those who later adopt the products (BROWN and VENKATESH, 2005). Several studies propose that perceived utility has a positive impact on the propensity for consumption, especially that of Duane, O'Reilly and Andreev (2014). The following hypothesis was built:

- $\quad$ H2(+): Perceived Usefulness positively influences the Engagement in the participation of actions of elective mandates in the Brazilian Legislative in the use of political techs.

\section{Personal Innovativeness}

Personal innovativeness is defined, according to Duane O'Reilly and Andreev (2014), as an individual's willingness to experience any new information technology. Personal innovativeness is an act of its own for each of the individuals and can be considered the same as innate innovation, which is part of an individual's personality (IM, KIM and HAN, 2008). Thus we elaborated the following hypotheses:

- $\quad \mathbf{H 3 a ( + ) : ~ P e r s o n a l ~ I n n o v a t i v e n e s s ~ p o s i t i v e l y ~ i n f l u e n c e s ~ t h e ~ P e r c e i v e d ~ U s e f u l n e s s ~ i n ~ t h e ~ p a r t i c i p a t i o n ~ o f ~ a c t i o n s ~ o f ~}$ elective mandates in the Brazilian Legislative in the use of political techs.

- $\quad \mathbf{H} \mathbf{3}(\mathbf{( + )}$ : Personal Innovativeness positively influences the Perceived Ease of Use in the participation of actions of elective mandates in the Brazilian Legislative in the use of political techs.

\section{Social Influence}

According to Venkatesh, Thong and Xu (2012), social influence is evidenced as users' realization that important people, such as family, friends or influential people in the media or in certain areas, believe they should use a specific technology (BROWN and VENKATESH, 2005). These hypotheses are formed to measure the influence and behavioral intent that the individual must use a technology. For Weeks, Ardèvol-Abreu and Zúniga (2017), the importance of the role of the internet and social media in politics contrasts with the fact that portions of the population engage less with news and political information. The authors suggest that these groups of people are influenced by other groups that are active in the search for information of apolitical nature. Thus we elaborated the following hypotheses:

- $\quad \mathbf{H 4 a ( + ) : ~ S o c i a l ~ I n f l u e n c e ~ p o s i t i v e l y ~ i n f l u e n c e s ~ t h e ~ E n g a g e m e n t ~ i n ~ t h e ~ p a r t i c i p a t i o n ~ o f ~ a c t i o n s ~ o f ~ e l e c t i v e ~ m a n d a t e s ~ i n ~}$ the Brazilian Legislative in the use of political techs.

- $\quad \mathbf{H} \mathbf{4 b}(+)$ : Social Influence positively influences the Trust in the participation and actions of elective mandates in the Brazilian Legislative in the use of political techs.

\section{Trust}

A user's sense of trust in relation to an online service is a determining factor when considering its use (CHAU, HU, LEE et al., 2006; ROCA, GARCIA and VEGA, 2008). Sanchez-Franco and Rondan-Cataluña (2010) believe that trust is the most important antecedent in this scenario. For Duane, O'Reilly and Andreev (2014), the greater the confidence and ethical commitment perceived by individuals in relation to the providers of the online service, the greater the intention of using an electronic platform. The following hypothesis is constructed:

- $\quad \mathbf{H 5 ( + )}$ : Trust positively influences the Engagement in the participation of actions of elective mandates in the Brazilian Legislative in the use of political techs. 
Study of citizen engagement in the participation of elective mandate actions in the Brazilian Legislature: analysis of the use of political techs
Jessica Natalia Souza Pavan | Luis Hernan Contreras Pinochet Gabriela de Brelàz | Durval Lucas dos Santos Júnior Daielly Melina Nassif Mantovani Ribeiro

\section{Engagement}

Given the different approaches that the engagement concept can present, the definition that applies most is to be involved, busy and interested in something (HIGGINS, 2006). For Vivek, Beatty, Dalela et al. (2014), engagement links to intrinsic and extrinsic values, in three main dimensions that combine cognitive-affective factors (enthusiasm), behavioral aspects (conscious participation) and social (social interaction) of the user. The author also demonstrates that the intensity of participation and the relationship between users and service providers are determinant for engagement to occur.

In addition, engagement and associates with the process of behavior change, make the individual an active agent in the communication process.

Duane, O'Reilly and Andreev (2014) model was used as the central basis of the study, with the following adaptations and modifications: a) the constructs "Perceived Ease of Use", "Perceived Usefulness", "Personal Innovativeness" and "Trust"; b) together with this model were also used the constructs "Social Influence" (VENKATESH, THONG and XU, 2012) and "Engagement" (VIVEK, BEATTYLA, DALE et al., 2014); c) from the six constructs used as the basis for the study, 23 assertions were adapted, excluding those related to the construct "Self-Efficacy"; and d) questions of socio-demographic origin were created to understand the profile of the respondents.

The theoretical model, its latent variables and their respective hypotheses, based on the assertions presented in Appendix A, resulted in Figure 1.

Figure 1

Theoretical model

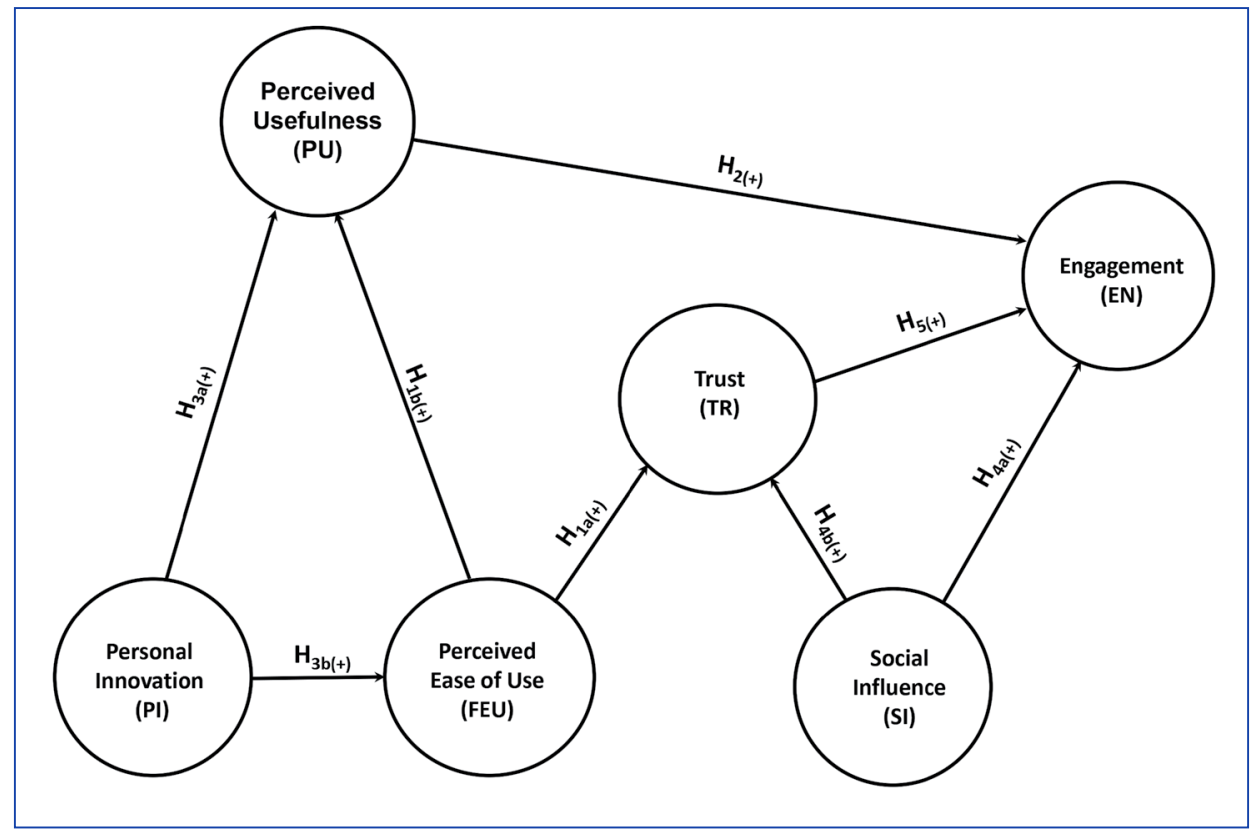

Source: Elaborated by the authors.

\section{METHOD}

The study had a quantitative approach of a descriptive nature, using the technique of application of a survey. The research instrument adopted a Likert scale, ranging from $1-I$ totally disagree - to 5 - totally agree - and the questionnaires were applied in person, with printed material. The survey is based on divided theoretical aspects and was grouped into constructs, that is, issues that deal with the same aspect. Data collection was carried out in October 2018, in the postelection period. 
Study of citizen engagement in the participation of elective mandate actions in the Brazilian Legislature: analysis of the use of political techs
Jessica Natalia Souza Pavan | Luis Hernan Contreras Pinochet Gabriela de Brelàz | Durval Lucas dos Santos Júnior Daielly Melina Nassif Mantovani Ribeiro

The selection criteria of the sample were young individuals and undergraduate or graduate students at four of the main universities in São Paulo city. This choice is justified as that audience has greater access to new technologies. In addition, it is understood that the university environment is open to debate and access to new forms of engagement and participation. Thus, the choice of the target audience aimed to identify the participation and political involvement of university students (individuals who relate to or belong to the university).

For the adaptation of the model to the Brazilian context, we use the reverse translation process and a pre-test was performed with 30 individuals, to verify whether there was an understanding of the research instrument. Considering that none of the participants had difficulty, the research was started with sample expansion. After the application of the test, 473 questionnaires were obtained in total and 467 final observations were obtained from the process of purification of the database.

In the descriptive analysis stage, information were analyzed regarding the demographic profile and socioeconomic data of the participants, as well as questions about the knowledge relative to the role of the Legislative Power and the use of applications to accompany the mandates and participate in the mandates in the Brazilian legislative power. This step of the work utilized Microsoft excel software and SPSS Statistics.

The multivariate method measured in this research was the modeling of structural equations. The regression by partial least squares (PLS), which is the correlations between the constructs and the variable, were measured through SmartPLS software, version 3.2.6. The modeling of structural equations is defined as the set of multivariate techniques that seeks the simultaneous analysis of theoretical relationships between variables. Aspects of multiple regression and factor analysis allow the researcher to verify multiple relationships of dependence and independence between the variables (HAIR, HULT, TOMAS et al., 2014).

\section{DATA ANALYSIS AND RESULTS}

In the 2018 general election, initiatives were expanded to foster participation in the choice of candidates with a profile closer to the convictions and beliefs of each citizen. There were also initiatives, both legislative assemblies and the National Congress, to create applications that would enable the monitoring of elective mandates. Likewise, there are political tech initiatives in non-profit organizations and private organizations. In view of this, the main technological initiatives of political techs were available in the Google Play Store and Apple Store in October 2018. Among the main ones are: a) FiscalizaCidadão; b) MeuVereador; c) NossoMandato; d) CoDeputado; e) Appoie; f) FalaCâmara; g) Aprovômetro; h) Câmara dos Deputados (EDO); i) Poder do Voto; and j) Mudamos+.

\section{Profile of respondents and specific questions about the Brazilian Legislative}

The profile of the research participants is presented to characterize the sample that provided support for the analysis of the propensity to use applications to participate in the elective mandates of the Legislative Power. Table 1 details information about gender, age, family income and educational level.

The audience analyzed in the sample presents male and female groups in equivalent percentages presented in a range of 17 to 50 years old. Some research participants aged up to 50 years are taking a new degree, while others area specialization course or MBA. Therefore, they are also part of the group of university students within the sample. The majority of the sample respondents are in the range of up to 25 years old $(76.2 \% / n=356)$ and $84.2 \%$ attend undergraduate $(n=393)$. Regarding the income of the respondents, the predominant stratum, according to the classification of the Associação Brasileira de Pesquisa (ABEP - Brazilian Research Association) was B2: individuals with monthly income sums of $\mathrm{R} \$ 4,852.00$ to $\mathrm{R} \$ 9,254.00$ (30.60\%/ $n=143)$.

Among the respondents, $75.6 \%$ ( $n=353$ ) claim to know the role of legislative, $24.2 \%$ don't know the role $(n=113)$ and 1 respondent marked the question blank. Of respondents who claim to know, $54.9 \%$ are men $(n=194)$ and $44.7 \%$ are women $(n=158)$; of those who do not know, $55.8 \%$ are women $(n=63)$ and $44.2 \%$ are men $(n=50)$. Of those who know the role of legislative, $71.8 \%(n=252)$ did not follow any mandate of the legislative and $28.2 \%(n=99)$ accompanied some mandate of the legislative. 
Study of citizen engagement in the participation of elective mandate actions in the Brazilian Legislature: analysis of the use of political techs
Jessica Natalia Souza Pavan | Luis Hernan Contreras Pinochet

Gabriela de Brelàz | Durval Lucas dos Santos Júnior Daielly Melina Nassif Mantovani Ribeiro

In the question of the reasons that led them not to follow the mandates, $48.4 \%$ ( $n=160)$ claimed disinterest, 19.6\% ( $n=65)$ reported that their candidate was not elected, $8.48 \%(n=28)$ said that the candidate disclosed little information and $23.3 \%$ $(n=77)$ mentioned other reasons.

Table 1

Demographic profile of participants

\begin{tabular}{|c|c|c|c|}
\hline & & $\mathrm{n}$ & $\%$ \\
\hline & Male & 244 & 52.2 \\
\hline \multirow[t]{4}{*}{ Sex } & Female & 222 & 47.5 \\
\hline & Blank & 1 & 0.2 \\
\hline & Total & 467 & 100 \\
\hline & Attending graduation & 393 & 84.2 \\
\hline \multirow[t]{6}{*}{ Education level } & Graduation completed & 34 & 7.3 \\
\hline & Attending postgraduate studies & 23 & 4.9 \\
\hline & Completed graduate & 17 & 3.6 \\
\hline & Total & 467 & 100 \\
\hline & Up to 25 years old & 356 & $76 ; 2$ \\
\hline & 26 to 30 years old & 66 & 14.1 \\
\hline \multirow[t]{8}{*}{ Age } & 31 to 35 years old & 27 & 5.7 \\
\hline & 36 to 40 years old & 12 & 2.5 \\
\hline & 41 to 50 years old & 5 & 1.07 \\
\hline & Blank & 1 & 0.2 \\
\hline & Total & 467 & 100 \\
\hline & Lower R\$ 768.00 & 2 & 0.4 \\
\hline & From $\mathrm{R} \$ 768.00$ to $\mathrm{R} \$ 1,625.00$ & 18 & 3.9 \\
\hline & From $\mathrm{R} \$ 1,625.00$ to $\mathrm{R} \$ 2,705.00$ & 62 & 13.3 \\
\hline \multirow[t]{6}{*}{ Family income } & $\mathrm{R} \$ 2,705.00$ to $\mathrm{R} \$ 4,852.00$ & 97 & 20.8 \\
\hline & $\mathrm{R} \$ 4,852.00$ to $\mathrm{R} \$ 9,254.00$ & 142 & 30.4 \\
\hline & $R \$ 9,254.00$ to $R \$ 20,888.00$ & 86 & 18.4 \\
\hline & Greater than $\mathrm{R} \$ 20,888.00$ & 46 & 9.9 \\
\hline & Blank & 14 & 3 \\
\hline & Total & 467 & 100 \\
\hline
\end{tabular}

Source: Elaborated by the authors.

\section{Analysis of normality}

Multivariate analysis techniques use metric variables and statistical tests, and multivariate normality is the fundamental condition of application (HAIR, HULT, TOMAS et al., 2014). The normality of the data was verified using the Kolmogorov-Smirnov test (K-S) and the respective $\mathrm{p}$-value of each variable. This procedure was necessary to limit the possibility of using some statistical analysis techniques that feature normal data distribution. All individual K-S test valves and $\mathrm{p}$-value for indicators resulted in "very significant" with $p<0.01$. Regarding predictor variables related to the latent variable "Engagement", it was possible to accommodate the multicollinearity in the model. 
Study of citizen engagement in the participation of elective mandate actions in the Brazilian Legislature: analysis of the use of political techs
Jessica Natalia Souza Pavan | Luis Hernan Contreras Pinochet Gabriela de Brelàz | Durval Lucas dos Santos Júnior Daielly Melina Nassif Mantovani Ribeiro

\section{Structural model analysis}

After the first iteration, the results of factorial loads obtained by latent variables were presented and it was observed that some factor loads indicated values below 0.5. For convergent validity adjustment (Cronbach's Alpha, Composite Reliability, Average Variance Extracted and Determination Coefficients), the variables EE1, with factorial load 0.476 and PU1 with 0.430 , are presented in Appendix A.

The convergent validity presented in Table 2 demonstrated the extent to which the latent variable correlates to the items chosen to measure that variable (BAGOZZI, YI and PHILLIPS, 1991).

Cronbach's Alpha coefficients varied between 0.543 to 0.833 , and values above 0.60 are considered adequate. This median result indicates that the coefficient is very sensitive to sample size. Scales were tested in a study object that is not part of people's daily lives (HELMS, 1999). The Composite Reliabilities obtained in this study ranged from 0.757 to 0.887 , indicating that the results were satisfactory in this sense.

For this model, the average variances extracted (AVEs) varied between 0.500 to 0.667 , which meets Chin (1998) criteria for the indication of convergent validity.

The value of Determination Coefficients $\left(R^{2}\right)$ measures the predictive accuracy of the model, representing the combined effects of endogenous variables on exogenous variables. In this research, the response variable "Engagement" was explained in $35.8 \%$ in the model.

According to the criterion used to evaluate the accuracy of the adjusted model, $\mathrm{Q}^{2}$, all constructs were considered adequate accuracy as they presented values greater than zero. The constructs "Personal Innovation" and "Social Influence" presented zero value, demonstrating the need for improvement in their accuracy, which is reasonable considering it is a new thematic which needs further study. The measurement of $f^{2}$ can be classified using cut off points between 0.02 and 0.15 as small, 0.15 to 0.35 as medians and values greater than 0.35 as large (HAIR, HULT, TOMAS et al., 2014). Finally, the quality of the overall adjustment measure (goodness of fit [GoF]), in the amount of $0.36(36 \%)$ was considered average for the validity of the model in PLS.

Table 2

Convergent validity

\begin{tabular}{lccccccc}
\hline \multicolumn{1}{c}{ Latent variables } & $\begin{array}{c}\text { Cronbach's } \\
\text { Alpha } \\
>0.60\end{array}$ & $\begin{array}{c}\text { Composite } \\
\text { Reliability }>0.70\end{array}$ & $\begin{array}{c}\text { Average Variance } \\
\text { Extracted (AVE) } \\
>0.50\end{array}$ & $R^{2}$ & $Q^{2}$ & $\begin{array}{c}\text { Number } \\
f^{2}\end{array}$ \\
\hline Trust & 0.749 & 0.844 & 0.580 & 0.217 & 0.115 & 0.098 & 4 \\
Engagement & 0.833 & 0.887 & 0.663 & 0.358 & 0.215 & 0.129 & 5 \\
Perceived Ease of Use & 0.687 & 0.797 & 0.500 & 0.170 & 0.073 & 0.204 & 4 \\
Personal Innovation & 0.663 & 0.814 & 0.593 & & & 3 \\
Social Influence & 0.543 & 0.757 & 0.513 & & 0.142 & 0.086 & 0.054 \\
Perceived Usefulness & 0.753 & 0.857 & 0.667 & & 4 \\
\hline
\end{tabular}

Source: Elaborated by the authors.

Discriminating validity evaluated items reflect the factor or are correlated with other factors. In this research, the extracted mean variances were higher or equal to the square of the correlation between the factors, as shown in Table 3, with the Fornell-Larcker criterion presenting all the factorial loads of each indicator with values above 0.5. 
Study of citizen engagement in the participation of elective mandate actions in the Brazilian Legislature: analysis of the use of political techs
Jessica Natalia Souza Pavan | Luis Hernan Contreras Pinochet

Gabriela de Brelàz | Durval Lucas dos Santos Júnior Daielly Melina Nassif Mantovani Ribeiro

Table 3

Discriminant validity: Fornell-Larcker criterion

\begin{tabular}{lcccccc}
\hline \multicolumn{1}{c}{ Variables I } & $(1)$ & $(2)$ & $(3)$ & $(4)$ & (5) & (6) \\
\hline (1) Trust & 0.761 & & & & & \\
(2) Engagement & 0.400 & 0.814 & & & & \\
(3) Perceived Ease of Use & 0.375 & 0.369 & 0.707 & & & \\
(4) Personal Innovation & 0.394 & 0.699 & 0.412 & 0.770 & & \\
(5) Social Influence & 0.375 & 0.521 & 0.297 & 0.487 & 0.716 & \\
(6) Perceived Usefulness & 0.360 & 0.460 & 0.310 & 0.324 & 0.486 & 0.817 \\
\hline
\end{tabular}

Note: The highlighted diagonal presents the square roots of stroke.

Source: Elaborated by the authors.

Other samples composed of elements of the original sample are developed and the parameters of the model are estimated (CHIN, 1998). In view of this, there was also no cross loads. The model proposed in this research was estimated using the bootstrapping technique, comparing the original sample with the samples generated by this technique. In this sense, another 500 samples were generated, and student's t-test was performed. The analysis of the significance of the paths can be verified from the $t$-values and the factorial loads of the observable variables. These values are interpreted based on Table 4.

Table 4

Analysis of the significance of the paths

\begin{tabular}{|c|c|c|c|c|c|}
\hline Hypotheses & Paths & $(\beta)$ & $\begin{array}{l}\text { Bootstrapping } \\
\text { of } 500\end{array}$ & $\begin{array}{l}\text { Standard } \\
\text { Error }\end{array}$ & T-Test \\
\hline $\mathrm{H} 1 \mathrm{a}(+)$ & Perceived Ease of Use-> Trust & 0.289 & 0.293 & 0.048 & 6.002 \\
\hline $\mathrm{H} 1 \mathrm{~b}(+)$ & $\begin{array}{l}\text { Perceived Ease of Use-> Perceived } \\
\text { Usefulness }\end{array}$ & 0.213 & 0.212 & 0.055 & 3.897 \\
\hline $\mathrm{H} 3 \mathrm{a}(+)$ & $\begin{array}{l}\text { Personal Innovation-> Perceived } \\
\text { Usefulness }\end{array}$ & 0.236 & 0.239 & 0.053 & 4.421 \\
\hline $\mathrm{H} 3 \mathrm{~b}(+)$ & $\begin{array}{l}\text { Personal Innovation-> Perceived } \\
\text { Ease of Use }\end{array}$ & 0.412 & 0.419 & 0.041 & 9.965 \\
\hline $\mathrm{H} 4 \mathrm{a}(+)$ & Social Influence-> Engagement & 0.340 & 0.340 & 0.046 & 7.397 \\
\hline $\mathrm{H} 4 \mathrm{~b}(+)$ & Social Influence-> Trust & 0.288 & 0.287 & 0.048 & 5.960 \\
\hline $\mathrm{H} 5(+)$ & Trust-> Engagement & 0.191 & 0.192 & 0.046 & 4.151 \\
\hline
\end{tabular}

Note: Significance - all results $p<0,001$.

Source: Elaborated by the authors.

The $\mathbf{H} \mathbf{3} \mathbf{b}$ hypothesis with the path "Personal Innovation -> Ease of Perceived Use" had the highest $\beta(0.412)$. Considering that Personal Innovation is characterized by the openness of the individual to try new technologies and new services (DUANE, O'REILLY and ANDREEV, 2014) and the Perceived Ease of Use is the notion that the use of a system should be free from great difficulties and effort to obtain the proposed results (DAVIS, 1989), the strong relationship between the two variables can be explained by the fact that when citizens seek tools such as those of the study, they expect applications to be easy to interact with and understand.

Using the tools can have a larger audience of users with personal characteristics linked to innovation. That is, those who will use will be people who already handle applications and understand that such mechanisms may constitute a way of expanding the political participation of citizens in Legislative Power. For this, accessibility and interactivity of the tools are critical for the user to feel comfortable and confident to use the applications (ERTIÖ, 2015). 
Study of citizen engagement in the participation of elective mandate actions in the Brazilian Legislature: analysis of the use of political techs
Jessica Natalia Souza Pavan | Luis Hernan Contreras Pinochet Gabriela de Brelàz | Durval Lucas dos Santos Júnior Daielly Melina Nassif Mantovani Ribeiro

\section{CONCLUSION}

The proposed model for this study was developed with the objective of analyzing citizen engagement by applications classified as political techs, in participation in elective mandate actions in the Legislative Power after the 2018 general election. As a basis for the research, constructs adapted and related to the theme were used, since there are still no specific models for the study in the area of public management.

All hypotheses raised in this study were supported based on the theoretical aspects presented $(p<0.001)$. It was evident that there is a $35.8 \%$ explanation for the engagement, not the use of political tech applications, which is considered acceptable, even though it is an early-stage technological resource in society. This is an indication that there is interest on the part of university students in adopting a technology that can bring greater information and visibility in the area of public management.

Engagement was considered an essential construct in this research so that the citizen can use applications and participate in mandates focused on Legislative Power. The more the citizen feels part of the process and start to recognize that he has an active voice in the interaction with the parliamentarian, the more engaged he becomes and thus becomes interested in using applications to actively participate in the legislative process.

It is essential to understand the importance of citizens to supervise and participate in decisions about the resources invested in public policies and actions. This generates the feeling of "belonging", to foster citizen engagement. According to Serra and Carneiro (2012), citizen engagement is social control in the evaluation of governments according to the performance in favor of the interest of the collectivity. Citizen's engagement requires the elected official to exhibit transparent and participatory action. This guarantees interaction and considers the proposals generated collective in the final decision - in the case of Legislative Power, in the proposal of bills and in parliamentary action.

The tools of political techs can help in the interaction and participation of the citizen in the legislative process, since they allow the referral of suggestions and ideas to parliamentarians (councilors/deputies/senators) and allow for sharing of information with other citizens seeking improvements. The big challenge, perhaps, is to filter and evaluate all the provided information and suggestions and provide participants with feedback on the reason a suggestion has been accepted or not. This is in addition to ensuring that users remain engaged, keeping an open channel with the citizen with "active interlocution" or, as mentioned by Higgins (2006), can keep the individual interested and involved in the initiatives.

Applications are a tool for social engagement; it is essential to create working groups in which the monitoring and proposals of projects are discussed, as well as to expose subsidies for decision-making in the votes and proposals of elected officials. However, for this to occur, an environment favorable to innovation and openness for participation and social control is necessary.

It is necessary that not only individuals, but also the rulers, understand that the State must work for the common good and participatory processes that allow to encompass more "voices to the same choir", leaving public interests to overlap with particular interests. In an optimistic view of the use of the tool, the motivation for the adoption should be the desire to participate in the decisions in the hope of substantial changes in the daily lives of people. This would expand involvement between rulers and governed, enabling the mobilization of several audiences and seeking to encompass all genders in the participatory process.

Even considering that the sample of this research had a specific audience of university students, it is important to note that this type of application can also be widely used, because, as analyzed by Vivek, Beatty, Dalela et al. (2014), engagement is linked to behavioral, social and emotional aspects that, combined, determine the intensity of the relationship between the individual and a given practice. Therefore, engagement is directly connected to the changed passive behavior for active behavior.

In this sense, it is expected that citizens nourish the feeling of being a "part" of the process, generating creative ideas and driving stakeholders to seek innovations that will be operationalized in the future. This brings citizens and government closer, generating greater accountability and a feeling of "responsiveness", assisting in the development of Brazilian democracy and making governments more accountable and transparent. 
Study of citizen engagement in the participation of elective mandate actions in the Brazilian Legislature: analysis of the use of political techs
Jessica Natalia Souza Pavan | Luis Hernan Contreras Pinochet Gabriela de Brelàz | Durval Lucas dos Santos Júnior Daielly Melina Nassif Mantovani Ribeiro

The characteristics raised above bring the reflection of a new concept that is used to analyze the engagement of the use of these applications, which is the citizen's engagement. This is the involvement and participation of the individual in response to the political, economic and social conditions of a nation (SABIONI, FERREIRA, BRAGA et al., 2016). The level of engagement is influenced by demographic and socioeconomic aspects.

As exposed during the study and observed by Fung (2006), there is no standard strategy to expand participation. However, important aspects should be considered for citizens in the use of technology, such as ease of use, security and cooperation with other means of participation. The relationship between internet use and civic engagement comes as users start employing apps to inform themselves, consult news on websites, share information with followers on networks, through platforms and applications, to shorten distance and promote debates focused on Brazilian politics (HILBERT, 2009; OSTMAN, 2012).

The use of political techs to participate in mandates presupposes that there is civic engagement, considering that political participation should take place before, during and after the election (EKMAN and AMNÅ, 2012). It is also necessary that parliamentarians participate in the Legislative Power be broader, democratic and reflect on the quality of matters discussed and approved in the Brazilian Legislature, as well as in the interest of the citizen's approach in political action in the country.

Much of the participation research agenda in Brazil prioritizes the relationship between citizens and the Executive Power. Even if it is not conclusive, the possible contribution of such tools to the deepening of democracy lies in providing different knowledge and angles to how campaigns involve voters. Political techs contribute technologies developed and used for political purposes, whether it is an application that aims to increase voter turnout or software that analyzes large volumes of data to understand parliamentarians.

With the opportunities offered by political techs, the risks should also be observed. Political technology can be applied in what can be considered inappropriate or unethical means. For example, personal data can be used to manipulate citizens through targeted advertising campaigns. In the same way that fake social media accounts, fake news or malicious political tech technologies can broaden visions that are not representative and expel genuine voices.

Equally, political techs can positively transform society and help deal with massive and complex problems. This technology can allow groups of people to communicate and organize with efficiency and convenience, opening political debates in previously private conversations in the digital public domain. These technology platforms can also help new candidates collect data and information in their campaigns and outline new communication strategies for engagement.

Given this context, political techs bring innovations that foster new methods of creating ideas and actions and enable the expansion of channels for the participation and deepening of the relationship between state and civil society. This also makes the institutional environment more complex, especially about policy formulation, coordination and implementation processes (PETINELLI, 2013; PIRES and GOMIDE, 2014).

Finally, the advancement of ICTs in Brazil, specifically when observing the phenomenon of political techs, opens a gap in the field of study that can contribute to the reduction of the crisis of democracy. This is observed through the lack of connection between the interest of those who vote and the interest of those elected, as well as their attitudes in the exercise of the mandate. This is the main foundation of the crisis of representative democracy, which plagues several countries, as is the case in Brazil. The control of voters regarding the acts practiced by the representatives can be observed from the pressure exerted on these and, above all, by the non-re-election of the parliamentary.

This study presents indications that political participation instrumentalized by political techs can result in achievable objectives that constitute the Brazilian democratic order. Thus, the use of cyberspace can ensure important mechanisms of participation and social control of the public, expanding the spaces of democratic coexistence and allowing the emergence of new political actors, which is not only up to cyberdemocracy, but to the whole society. 
Study of citizen engagement in the participation of elective mandate actions in the Brazilian Legislature: analysis of the use of political techs
Jessica Natalia Souza Pavan | Luis Hernan Contreras Pinochet Gabriela de Brelàz | Durval Lucas dos Santos Júnior Daielly Melina Nassif Mantovani Ribeiro

\section{Recommendations for management}

Based on the results of the study, the focus should be on suggestions for the actions of the agents involved (government, elected parliamentarians, citizens, entities and partner companies of governments), so that applications succeed, and what are the potential benefits.

The first consideration is consistent with the interest of governments in having popular participation as part of the agenda of the mandates and seek actions and projects aimed at the expansion and approximation between State and society. They seek to make applications with easy handling interface available to the population, disseminating and institutionalizing the use of technology as a method of involvement as a form of citizen participation with more accessible language.

When we begin to reflect on the role of the citizen, we observe that, in the same way as the government and parliamentarians, it can also contribute to the opening and participation of the processes and limits of each level of government. It is necessary, at this point, to expand issues related to public management, fundamental for the development of the country, in environments committed to the formation of citizens. There should be no "resistance in learning" of citizens and "clearer explanations" are expected by the influencer agents in the formation of society, and the success or failure of this dialectical practice will reflect directly on the political issue.

Accordingly, agents who conduct and transmit the information should be sufficiently prepared to carry out such activity with clarity and for the purpose of bringing knowledge and information to the most vulnerable portion of the population. As observed by Avritzer (2008), participatory spheres are composed not only of formal institutions, but also by social agents with weight in the decision-making of the citizen.

Public personalities have been using these types of technology to engage and bring citizens closer to public actions, which demonstrates that political techs have been gaining space as a tool for social control and monitoring of government actions, being incorporated by elected parliamentarians and public personalities who influence citizens. In the same perspective, being processed in the Chamber of Deputies is the law project 9.617/2018, which establishes shared management, aimed at the budgetary, financial and physical monitoring of the execution of works, by groups of citizens organized in aggregating applications available on the Internet, demonstrating, once again, that the use of applications constitutes an innovation object in the public sector.

A caveat to the new technologies of political techs, especially those who suggest candidates who most closely resemble the profile of those who are conducting the search, would be the need for monitoring and involvement of the Tribunal Superior Electoral (TSE). They would act as a supervisory body regarding the transparency of the method and the analytical methodologies that keep them available in apps or websites. In this sense, technology should not be used to direct the vote without the user being fully aware of how the application brings possible results.

Therefore, it is suggested - for future research in the field of the use of applications to expand social participation, whether in the Legislative, Executive or Judiciary Power - and to widen the applications to include different social strata, especially with regard to income, age and schooling, obtaining a more heterogeneous sample. 
Study of citizen engagement in the participation of elective mandate actions in the Brazilian Legislature: analysis of the use of political techs
Jessica Natalia Souza Pavan | Luis Hernan Contreras Pinochet Gabriela de Brelàz | Durval Lucas dos Santos Júnior Daielly Melina Nassif Mantovani Ribeiro

\section{REFERENCES}

ADLER, R. P.; GOGGIN, J. What do we mean by "civic engagement"? Journal of Transformative Education, v. 3, n. 3, p. 236-253, 2005.

AVRITZER, L. Instituições participativas e desenho institucional: algumas considerações sobre a variação da participação no Brasil democrático. Opinião Pública, v. 14, n. 1, p. 43-64, 2008.

BAGOZZI, R. P.; YI, Y.; PHILLIPS, L. W. Assessing construct validity in organizational research. Administrative Science Quarterly, v. 36, n. 3, p. 421-458, 1991.

BIMBER, B. Information and political engagement in America: the search for effects of information technology at the individual level. Political Research Quarterly, v. 54, n. 1, p. 53-67, 2001.

BROWN, S. A.; VENKATESH, V. Model of adoption of technology in households: a baseline model test and extension incorporating household life cycle. MIS Quarterly: Management Information Systems, v. 29, n. 3, p. 399-426, 2005.

CHAU, P. Y. K. et al. Examining customers' trust in online vendors and their dropout decisions: an empirical study. Electronic Commerce Research and Applications, v. 6, n. 2, p. 171-182, 2006.

CHEN, W. A moveable feast: do mobile media technologies mobilize or normalize cultural participation? Human Communication Research, v. 41, n. 1, p. 82-101, 2015.

CHIN, W. W. The partial least squares approach for structural equation modeling. In: MARCOULIDES, G. A. (Ed.). Modern methods of business research. Mahwah: Lawrence Erlbaum, 1998. p. 295-336.

CUNHA, M. A. V. C.; MIRANDA, P. R. M. O uso de TIC pelos governos: uma proposta de agenda de pesquisa a partir da produção acadêmica e da prática nacional. Organizações \& Sociedade, v. 20, n. 66, p. 543-566, 2013.

DAVIS, F. D. Perceived usefulness, perceived ease of use, and user acceptance of information technology. MIS Quarterly, v. 13, n. 3, p. 319-339, 1989.

DINIZ, E. H. et al. O governo eletrônico no Brasil: perspectiva histórica a partir de um modelo estruturado de análise. Revista de Administração Pública, v. 43, n. 1, p. 23-48, 2009.

DUANE, A.; O'REILLY, P.; ANDREEV, P. Realising M-payments: modelling consumers' willingness to M-pay using smart phones. Behaviour \& Information Technology, v. 33, n. 4, p. 318-334, 2014.

EKMAN, J.; AMNÅ, E. Political participation and civic engagement: towards a new typology. Human Affairs, v. 22, n. 3, p. 283-300, 2012.

ERTIÖ, T. Participatory apps for urban planning: space for improvement. Planning Practice \& Research, v. 30, n. 3, p. 303-321, 2015.

FOTH, M.; BRYNSKOV, M. Participatory action research for civic engagement. In: GORDON, E.; MIHAILIDIS, P. (Ed.). Civic media: technology, design, practice. Cambridge: The MIT Press, 2016. p. $563-580$.

FUNG, A. Varieties of participation in complex governance. Public Administration Review, v. 66, n. 1, p. 66-75, 2006.

FUNG, A.; GILMAN, H. R.; SHKABATUR, J. Six models for the internet + politics. International Studies Review, v. 15, p. 30-47, 2013.
GIDDENS, A. Modernity and self-identity: self and society in the late modern age. Stanford: Stanford University Press, 1991.

HAIR, J. F. et al. A primer on partial least squares structural equation modeling (PLS-SEM). Thousand Oaks: Sage, 2014.

HELMS, J. E. Another meta-analysis of the white racial identity scale's Cronbach alphas: implications for validity. Measurement and Evaluation in Counseling and Development, v. 32, n. 3, p. 122-137, 1999.

HIGGINS, T. E. Value from hedonic experience and engagement. Psychological Review, v. 113, n. 3, p. 439-460, 2006.

HILBERT, M. The maturing concept of e-democracy: from e-voting and online consultations to democratic value out of jumbled online chatter. Journal of Information Technology \& Politics, v. 6, n. 2, p. 87-110, 2009.

HIRZALLA, F.; ZOONE, L. V.; RIDDER, J. Internet use and political participation: reflections on the mobilization/normalization controversy. The Information Society, v. 27, n. 1, p. 1-15, 2010.

HSU, M. H.; CHANG, C. M.; YEN, C. H. Exploring the antecedents of trust in virtual communities. Behaviour and Information Technology, v. 30, n. 5, p. 587-601, 2011.

IM, I.; KIM, Y.; HAN, H. J. The effects of perceived risk and technology type on users' acceptance of technologies. Information \& Management, v. 45, n. 1, p. 1-9, 2008.

KARDAN A. A.; SADEGHIANI, A. Is e-government a way to e-democracy? A longitudinal study of the Iranian situation. Government Information Quarterly, v. 28, n. 4, p. 466-473, 2011.

KIM, B. J.; KLEINSCHMIT, S. W. A logistic multilevel model for civic engagement and community group impact in the digital age. In: GILGARCIA, J. R.; HELBIG, N.; OJO, A. (Ed.). ICEGOV '12. New York: ACM Press, 2012. p. 34-37.

KIM, K. J.; SUNDAR, S. S. Does screen size matter for smartphones? Utilitarian and hedonic effects of screen size on smartphone adoption. Cyberpsychology, Behavior \& Social Networking, v. 17, n. 7, p. 466473, 2014.

KLEIN, A. D. Transparência do orçamento público municipal: desenvolvimento de uma ferramenta (aplicativo) digital capaz de monitorar em tempo real o Legislativo municipal de São Leopoldo (RS). Colóquio: Revista do Desenvolvimento Regional, v. 16, n. 2, p. 207-224, 2019

MARTIN. J. A. Mobile media and political participation: defining and developing an emerging field. Mobile Media \& Communication, v. 2, n. 2, p. 173-195, 2014.

MILANI, C. R. S. O princípio da participação social na gestão de políticas públicas locais: uma análise de experiências latino-americanas e europeias. Revista de Administração Pública, v. 42, n. 3, p. 551579, 2008.

OSTMAN, J. Information, expression, participation: how involvement in user-generated content relates to democratic engagement among young people. New Media and Society, v. 14, n. 6, p. 1004-1021, 2012.

PAULA, M. T.; AFONSO, M. L. M. Formação de jovens para a participação política e o exercício da cidadania: uma intercessão entre direito 
Study of citizen engagement in the participation of elective mandate actions in the Brazilian Legislature: analysis of the use of political techs
Jessica Natalia Souza Pavan | Luis Hernan Contreras Pinochet Gabriela de Brelàz | Durval Lucas dos Santos Júnior Daielly Melina Nassif Mantovani Ribeiro e educação. Revista de Educação do Vale do São Francisco, v. 8, n. 16, p. 56-78, 2018.

PETINELLI, V. Contexto político, natureza da política, organização da sociedade civil e desenho institucional. In: AVRITZER, L.; SOUZA, C. L. (Orgs.). Conferências nacionais. Brasília, DF: Instituto de Pesquisa Econômica Aplicada, 2013. p. 207-242.

PIRES, R. C.; GOMIDE, A. A. Burocracia, democracia e políticas públicas. Brasília, DF: Instituto de Pesquisa Econômica Aplicada, 2014. (Texto para Discussão, n. 1940).

ROCA, J. C.; GARCIA, J. J.; VEGA, J. J. The importance of perceived trust, security and privacy in online trading systems. Information Management \& Computer Security, v. 17, n. 2, p. 96-113, 2008.

SABIONI, M. et al. Contextos (in)adequados para o engajamento cidadão no controle social. Revista de Administração Pública, v. 50, n. 3, p. 477-500, 2016.

SANCHEZ-FRANCO, M.; RONDAN-CATALUÑA, F. J. Connection between customer emotions and relationship quality in online music services. Behaviour \& Information Technology, v. 29, n. 6, p. 633-651, 2010.

SECCHI, L. Modelos organizacionais e reformas da administração pública. Revista de Administração Pública, v. 43, n. 2, p. 247-369, 2009.

SECCHI, M.; ALLEGRETTI, G.; TANG, A. Escalas híbridas de engajamento social: como a integração de tecnologias pode ampliar os processos participativos? In: BALBIM, R. (Org.). Geopolítica das cidades: velhos desafios, novos problemas. Brasília, DF: Instituto de Pesquisa Econômica Aplicada, 2016. p. 213-246.

SERRA, R. C. C.; CARNEIRO, R. Controle social e suas interfaces com os controles interno e externo no Brasil contemporâneo. Espacios Públicos, v. 15, n. 34, p. 43-64, 2012.

SPOSITO, M. P.; TARÁBOLA, F. S. Experiência universitária e afiliação: multiplicidade, tensões e desafios da participação política dos estudantes. Educação \& Sociedade, v. 37, n. 137, p. 1009-1028, 2016.
SUSSKIND, J. Future politics: living together in a world transformed by tech. Oxford: Oxford University Press, 2018.

TOWNER, T. L.; MUÑOZ, C. L. Baby boom or bust? The new media effect on political participation. Journal of Political Marketing, v. 17, n. 1, p. 32-61, 2016.

VENKATESH, V. L.; THONG, J. Y.; XU, X. Consumer acceptance and use of information technology: extending the unified theory of acceptance and use of technology. MIS Quarterly, v. 36, n. 1, p. 157-178, 2012.

VIEHLAND, D.; YOONG LEONG, R. S. Consumer willingness to use and pay for mobile payment services. International Journal of Principles and Applications of Information Science and Technology, v. 3, n. 1, p. 34-46, 2010.

VIVEK, S. D. et al. A generalized multidimensional scale for measuring customer engagement. Journal of Marketing Theory and Practice, v. 22 , n. 4, p. 401-420, 2014.

WEEKS, B. E.; ARDÈVOL-ABREU, A.; ZÚNIGA, H. G. Online influence? Social media use, opinion leadership, and political persuasion, International Journal of Public Opinion Research, v. 29, n. 2, p. 214-239, 2017.

YAMAMOTO, M.; KUSHIN, M. J.; DALISAY, F. Social media and mobiles as political mobilization forces for young adults: examining the moderating role of online political expression in political participation. New Media \& Society, v. 17, n. 6, p. 880-898, 2013.

YETANO, A.; ROYO, S. Keeping citizens engaged. Administration \& Society, v. 49, n. 3, p. 394-422, 2016.

ZHENG, Y. Explaining citizens' e-participation usage: functionality of e-participation applications. Administration \& Society, v. 49 n. 3, p. 423-442, 2015.

ZOLOTOV, M. N.; OLIVEIRA, T.; CASTELEVN, S. E-participation adoption models research in the last 17 years: a weight and meta-analytical review. Computers in Human Behavior, v. 81, p. 350-365, 2018. 
Study of citizen engagement in the participation of elective mandate actions in the Brazilian Legislature: analysis of the use of political techs
Jessica Natalia Souza Pavan | Luis Hernan Contreras Pinochet Gabriela de Brelàz | Durval Lucas dos Santos Júnior Daielly Melina Nassif Mantovani Ribeiro

Jessica Natalia Souza Pavan

ORCID: https://orcid.org/00000-0002-8931-4828

Master in Management of Policies and Public Organizations by the São Paulo School of Politics, Economics and Business (EPPEN) of the Federal University of São Paulo (UNIFESP); Bachelor of Public Administration from the State University of Santa Catarina (UDESC); Technical Advisor to the São Paulo State Government Secretariat, Osasco-SP, Brazil. E-mail: jehpavan@gmail.com

Luis Hernan Contreras Pinochet ORCID: https://orcid.org/0000-0003-2088-5283

Ph.D. from the School of Business Administration of São Paulo, Fundação Getulio Vargas of São Paulo (FGV EAESP); Adjunct professor at the Academic Administration Department of the Paulista School of Politics, Economics and Business (EPPEN) at the Federal University of São Paulo (UNIFESP), Osasco- SP, Brazil. E-mail: luis.hernan@unifesp.br

Gabriela de Brelàz

ORCID: https://orcid.org/0000-0001-9954-5526

Ph.D. from the School of Business Administration of São Paulo, Fundação Getulio Vargas of São Paulo (FGV EAESP); Professor at the Academic Administration Department at the Paulista School of Politics, Economics and Business (EPPEN) at the Federal University of São Paulo (UNIFESP), Osasco- SP, Brazil. E-mail: gabriela.brelaz@unifesp.br

Durval Lucas dos Santos Júnior ORCID: https://orcid.org/0000-0001-7989-5000

Ph.D. in Business Administration from the Faculty of Economics, Business and Accounting at the University of São Paulo (FEA/USP); Professor at the Academic Administration Department at the Paulista School of Politics, Economics and Business (EPPEN) at the Federal University of São Paulo (UNIFESP), Osasco - SP, Brazil. E-mail: durval.lucas@unifesp.br

Daielly Melina Nassif Mantovani Ribeiro

ORCID: https://orcid.org/0000-0001-6320-3268

Ph.D. in Business Administration from the Faculty of Economics, Business and Accounting at the University of São Paulo (FEA/USP); Professor, Department of Administration, Faculty of Economics, Administration and Accounting, University of São Paulo (FEA/USP), São Paulo - SP, Brazil. E-mail: daielly@usp.br 
Study of citizen engagement in the participation of elective mandate actions in the Brazilian Legislature: analysis of the use of political techs
Jessica Natalia Souza Pavan | Luis Hernan Contreras Pinochet

Gabriela de Brelàz | Durval Lucas dos Santos Júnior Daielly Melina Nassif Mantovani Ribeiro

\section{APPENDIX}

\section{Appendix A \\ Scale used in research}

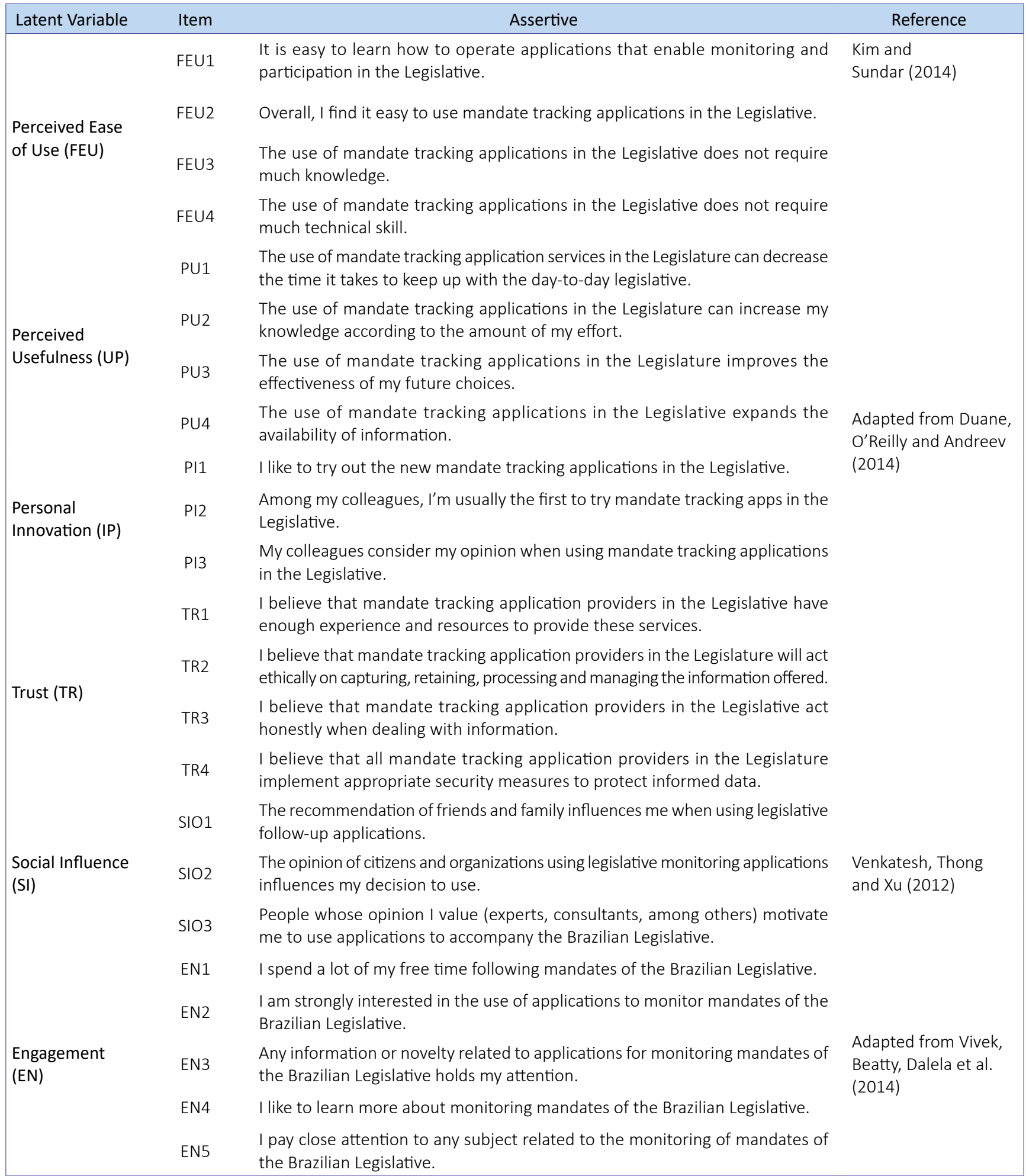

Source: Elaborated by the authors. 